\title{
The role of scurvy in Scott's return from the South Pole
}

\author{
AR Butler \\ Honorary Professor of Medical Science, Medical School, University of St Andrews, Scotland, UK
}

\begin{abstract}
Scurvy, caused by lack of vitamin C, was a major problem for polar explorers. It may have contributed to the general ill-health of the members of Scott's polar party in 1912 but their deaths are more likely to have been caused by a combination of frostbite, malnutrition and hypothermia. Some have argued that Oates's war wound in particular suffered dehiscence caused by a lack of vitamin C, but there is little evidence to support this. At the time, many doctors in Britain overlooked the results of the experiments by Axel Holst and Theodor Frølich which showed the effects of nutritional deficiencies and continued to accept the view, championed by Sir Almroth Wright, that polar scurvy was due to ptomaine poisoning from tainted pemmican. Because of this, any advice given to Scott during his preparations would probably not have helped him minimise the effect of scurvy on the members of his party.
\end{abstract}

KEYWORDS Polar exploration, scurvy, Robert Falcon Scott, Lawrence Oates

\author{
Correspondence to AR Butler, \\ Purdie Building, \\ University of St Andrews, \\ St Andrews KYI6 9ST, \\ Scotland, UK
}

tel. +44 (0)/334 474720 e-mail arb3@st-andrews.ac.uk

DECLARATIONS OF INTERESTS No conflicts of interest declared.

\section{INTRODUCTION}

The year 2012 marked the centenary of Robert Falcon Scott's tragic death on his return from the South Pole, having been beaten to it by the Norwegian Roald Amundsen.' Amundsen's dash to the Pole, although not devoid of hardship and setback, was relatively crisisfree and he and the other members of his party (Olav Bjaaland, Helmer Hanssen, Sverre Hassel and Oscar Wisting) returned to base camp in good health and had, in fact, put on weight during the journey. ${ }^{2}$ In contrast, the return of Scott and the four other members of his party (Lawrence Oates, Henry Bowers, Edward Wilson and Edgar Evans) from the Pole was beset by mishap and tragedy almost as soon as they started out (Figure I). After only a few weeks Evans had a fall from which he did not recover and he died soon after, though it is not clear whether the fall was the cause. Even at this early stage no member of the party was in good health. Some weeks later they were confined in a tent by a blizzard; Oates left the tent and was not seen again, an act which has subsequently been regarded as a deliberate sacrifice to allow the others a chance of survival. Although by this stage the remaining three members of the party were only II miles from One Ton Depot where there was fuel and food, they could go no further. Some historians believe that Wilson and Bowers could have continued but Scott held them back or they did not want to leave him. They

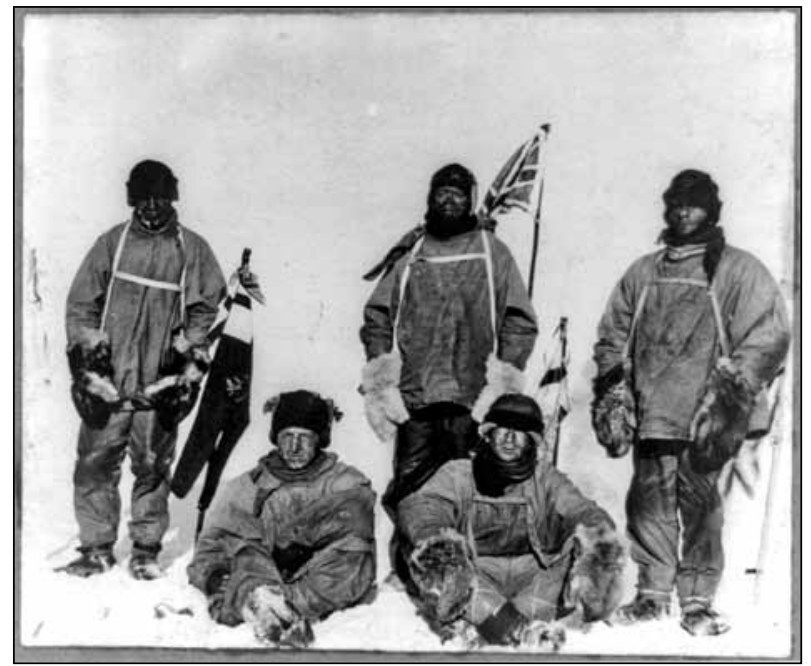

FIGURE I Members of the Terra Nova expedition at the South Pole: Robert F Scott, Lawrence Oates, Henry R Bowers, Edward A.Wilson, and Edgar Evans (photographer: Herbert J Ponting). From the Library of Congress.

all died in their sleeping bags; their bodies and personal effects were discovered some months later by a search party. Why did they die? Was it simply starvation and exhaustion or was it scurvy? Although we can never know for sure, there is a certain amount of medical evidence that sheds light on these questions. 


\section{SCURVY AND POLAR TRAVEL}

\section{The causes of scurvy}

Scurvy posed a significant problem for polar explorers in the nineteenth century as it had done for sailors in the previous century. Its cause is now known to be lack of vitamin $C$ but in those times the concept of vitamins, trace substances that had a profound effect on human health, was unknown. While Frederick Gowland Hopkins's seminal paper ${ }^{3}$ on what he called 'accessory food factors' did not appear until 1912, the concept was a familiar one before then. In a model clinical trial in 1747, James Lind, a Scottish naval surgeon, found a reliable treatment for scurvy: fresh lemons. ${ }^{4}$ Humans, other higher apes, some monkeys and guinea pigs are the only animals that cannot synthesise their own vitamin $C$ and need to obtain it from an exogenous source; we can only store vitamin $C$ in sufficient quantity to last two or three months. After the publication of Lind's results, the Royal Navy solved the problem of scurvy on long sea voyages by distributing fresh lemon juice (always called lime juice) to sailors. This worked well until lemons from Malta and Spain were replaced by the bottled juice of limes grown in the BritishWest Indies and scurvy reappeared. ${ }^{5}$ Limes contain much less vitamin $C$ than lemons, and during the extraction process, the juice was pumped through copper pipes which catalysed the oxidation of vitamin C. ${ }^{6}$ With the passage of time it therefore appeared that the navy did not have a prophylactic for scurvy after all. At the same time, the quality of food on board ship improved, sea travel was faster and the problem receded, particularly if the sailors were healthy enough to have a store of vitamin $C$ before the voyage started. In spite of the success of Lind's study, by the beginning of the twentieth century the early confidence that a successful treatment for scurvy had been found had gone.

For polar travellers the situation was somewhat different from that of sailors, for whom revictualling was possible. Polar journeys normally lasted many months or even years, much longer than the store of vitamin $C$ in the human body, and for much of the time no fresh food was available. The normal source of nourishment for polar travellers was pemmican, a food that North American trappers learned of from the Cree Indians. It consists of blocks of ground dried meat (generally beef) and fat, although sometimes small amounts of other materials are added. It is very high in calories, has an unpleasant taste and is not very palatable. The high calorie to weight ratio (6 kcal per g) is its only virtue. It is, however, very low in vitamin C, so it is not surprising that scurvy was commonplace among polar travellers.

\section{The clinical features of scurvy}

The features of scurvy change with the severity of vitamin C deprivation. Initially the features may include lassitude, general depression and cutaneous abnormalities but with the passage of time more strident physical signs appear, including bleeding gums, loose teeth, lower limb oedema and blurred vision. There may be dyspnoea, possibly due to anaemia. Minor cuts do not heal largely because vitamin $C$ is a powerful antioxidant, removing radicals that would otherwise hinder the wound healing process. ${ }^{7}$ Acute scurvy can cause death and is clearly a considerable hazard on a long polar journey. The cause, at the time, was thought to be ptomaine (or food) poisoning due to tainted or infected pemmican. However, the nature of ptomaine poisoning was ill-defined and there was little clinical evidence to support this view.

\section{Prevention of scurvy during the 1901 expedition}

In contrast to the confusion surrounding the cause of polar scurvy, the means of avoiding it was well-known to most polar explorers: consumption of fresh food by 'living off the land'. Scott was well-aware of the dangers of scurvy as it had been prevalent in base camp during his 1901 Discovery expedition and, with greater severity, during summer training excursions. Ernest Shackleton became so ill with scurvy that he had to return to New Zealand. ${ }^{8}$ One member of Scott's 1901 party (Dr Reginald Koettlitz) spent three years in the Arctic as a member of the Jackson-Harmsworth expedition and had noted that scurvy was not a serious problem for them. This he credited to regularly eating fresh meat (seal and penguin). He tried to persuade Scott that everyone should eat fresh penguin meat frequently. Scott disagreed because he thought the slaughter of so many penguins was cruel and would not be well-received by the British public. He allowed a few meals of penguin but not enough to make a significant difference to health. In any event, the cook made no attempt to make the penguin meat palatable and it was unpopular. One member of the party (Michael Barne) described it as tasting of 'shoe leather steeped in turpentine'.' Soon mild scurvy was rife. When Scott was away on a trip, Albert Armitage, a $P$ \& $O$ line officer with Arctic experience, was left in charge and insisted on meals of penguin meat and, possibly more significantly, the cook found better ways of preparing it. The situation improved to such an extent that even Scott was impressed when he returned, and he allowed the new regimen to continue.

\section{Scurvy and the second expedition}

Although the expedition of 1901 had alerted Scott to the dangers of scurvy for polar travellers, it is not clear that he applied these experiences to the diet of the shore party during the first Antarctic winter of his second expedition. They certainly had meals including fresh meat but also regularly ate pemmican. In contrast, Amundsen was absolute in his resolve to prevent scurvy. 
In his account of his expedition he states:

It was my plan to devote the entire winter to working on our outfit, and to get as near perfection as possible. Another thing to which we should have to give some time was the killing of a sufficient number of seals to provide fresh meat for ourselves and our dogs for the whole time. Scurvy, the worst enemy of Polar expeditions, must be kept off at all costs. And to achieve this it is my intention to use fresh meat every day. ${ }^{10}$

He claims also that he chose the Bay of Whales for his base camp because of reports of the abundance of animal life there.

\section{SCURVY AND ALMROTH WRIGHT}

Had Scott consulted medical opinion back in Britain he would have found general support for the ptomaine poisoning theory. Importantly, this was the view of one of the most powerful figures in British medicine at the time: Sir Almroth Wright. Although a respected medical scientist with a number of significant discoveries to his credit, he was stubbornly wrong on a number of issues; he was familiarly and disrespectfully nicknamed 'Sir Almost Wright' or even 'Sir Always Wrong." In the case of scurvy the latter sobriquet seems justified. In 1900 he published a paper in The Lancet ${ }^{12}$ stating that scurvy was due to acidosis following ptomaine poisoning, a view he refused to change until 1937 when one of his junior colleagues, LC Holt, produced conclusive experimental evidence that it was caused by a dietary deficiency. ${ }^{13}$ Scott's acceptance of Wright's view was reinforced when, during the Antarctic winter of 1911, Edward Atkinson (a doctor) lectured to the polar party on scurvy. It is illuminating to see the entry in Scott's diary for that occasion (Figure 2):

Sir Almroth Wright has hit the truth, he (Atkinson) thinks, in finding increased acidity of blood - acid intoxication - by methods only possible in recent years... In brief, he holds the first cause to be tainted food but secondary or contributory causes may be even more potent in developing the disease. Damp, cold, over-exertion, bad air, bad light, in fact, any condition exceptional to normal healthy existence. Remedies are to change these conditions for the better. ${ }^{14}$

Sir Almroth's obduracy is particularly damaging to his reputation as two Norwegian scientists, Axel Holst and Theodor Frølich had, in 1907, published two lengthy papers proving conclusively from experiments on guinea pigs that scurvy was caused by what they described as 'a one-sided diet' and that it could be cured by changes in eating habits. ${ }^{15,16}$ These papers were

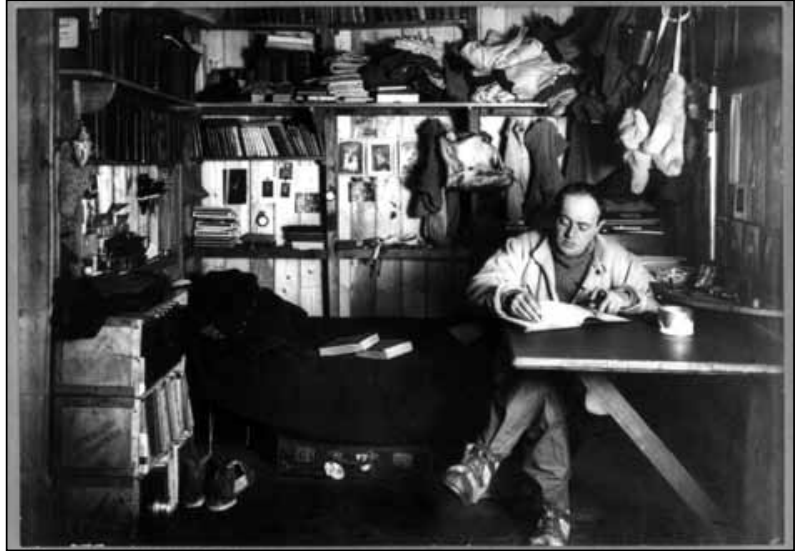

FIGURE 2 Captain Robert F Scott writing in his diary during the British Antarctic Expedition, 1910 or 1911 (photographer: Herbert J Ponting). From the Library of Congress.

complex but Wright and other members of the medical establishment in Britain would have been aware of their findings. It is not to be expected that Scott would be aware or read them but the ignorance of the medical establishment is surprising. To his credit Eric Marshall, the doctor in Shackleton's 1908 expedition, had read the papers and insisted that the party had as much fresh food as possible, including seal meat, thus largely avoiding scurvy. ${ }^{17}$ Although Scott and Shackleton did not get on well, Scott could still have benefitted from his experience.

\section{FRIDTJOF NANSEN}

Another person to whom Scott turned for advice also served him badly, possibly as a result of personal bias. In 1910 Scott took a motor sledge to Norway to test it on frozen Lake Mjøsen. While there he met Fridtjof Nansen, one of the pioneers of polar travel. Nansen was a towering figure in his time, best known later as an international statesman with the League of Nations, but he was also a neuroscientist, polar explorer, disciple of the clothing reformer Dr Gustav Jaeger and Rector of St Andrews University (1925-8). In 1888, as a student at the University of Christiania (now Oslo), he defended his doctoral thesis; one of the examiners was Professor Axel Holst who challenged his findings so thoroughly that he thought his thesis might be rejected. When Holst and Frølich later published their papers on scurvy, Nansen wrote a vitriolic letter to a newspaper ridiculing the work and advised Scott to ignore it. How far this response was a genuine scientific judgment and how much was revenge for the way he had been treated during his doctoral examination is difficult to say, but it remained ill-advised. Nansen however was alarmed at Scott's hasty and ill-conceived preparations for the expedition and advised him to take dogs for pulling the sledges rather than relying on man-hauling, but this 
advice was rejected. Scott's experience of dogs during his previous Antarctic expedition, admittedly in the hands of inexperienced drivers, was not positive. On the other hand, he did take Nansen's advice on the use of skis, although he had little skill or experience. ${ }^{18}$

\section{ROALD AMUNDSEN}

Amundsen seems to have been unaware of the Holst and Frølich paper and Nansen, who gave him every possible support, appears not to have mentioned it. Instead, Amundsen relied on Nordic traditions and folklore. The northern peoples of Scandinavia travelled extensively in cold conditions through barren country but rarely displayed symptoms of scurvy. They ate fresh seal meat and the native cloudberries (Rubus chanaemorus), both of which have been shown to be sources of vitamin C, particularly the latter which is even better than lemons. ${ }^{19}$ At Amundsen's base camp the cook regularly served pancakes covered with preserved cloudberries for breakfast, a meal much enjoyed by the party. Their diet also included fresh seal meat and so, by the time the party set off for the South Pole, the men had built up stores of vitamin $C$. Amundsen learned much from his previous polar expeditions and applied it to his dash to the South Pole. His careful and informed preparations brought him the success he so singlemindedly sought.

\section{HEALTH AND POLAR TRAVEL}

Before considering scurvy as a cause of death in Scott's polar party on the return from the Pole, other possible causes of ill-health must be considered. Frostbite was an obvious one.The extremities of the body are particularly susceptible to cold and, for the performance of certain bodily functions, the removal of gloves was necessary. At temperatures of $-40^{\circ} \mathrm{C}$ that carried obvious risks and speed was of the essence. Scott mentions in his diary that members of the party had severe frostbite. It was painful and debilitating but probably not lethal. However, it almost certainly contributed to the appalling state of health of Scott's party at the end.

A much more serious problem was malnutrition. In Amundsen's polar party the sledges carrying food and fuel were pulled by dogs and the human members of the party used skis for travel. As the sledges were emptied some dogs were shot, as planned, and used as food for the remaining dogs, a procedure that Scott did not like, although in extremis he did the same with ponies. The calorific value of Amundsen's food ration has been estimated at $4,560 \mathrm{kcal}$ per man per day, substantially above that required by a regular manual worker $(3,600$ $\mathrm{kcal}){ }^{20,21}$ Such was the success of Amundsen's planning and speed that he was able to increase the daily food ration to $5,000 \mathrm{kcal}$ on the return from the Pole and,

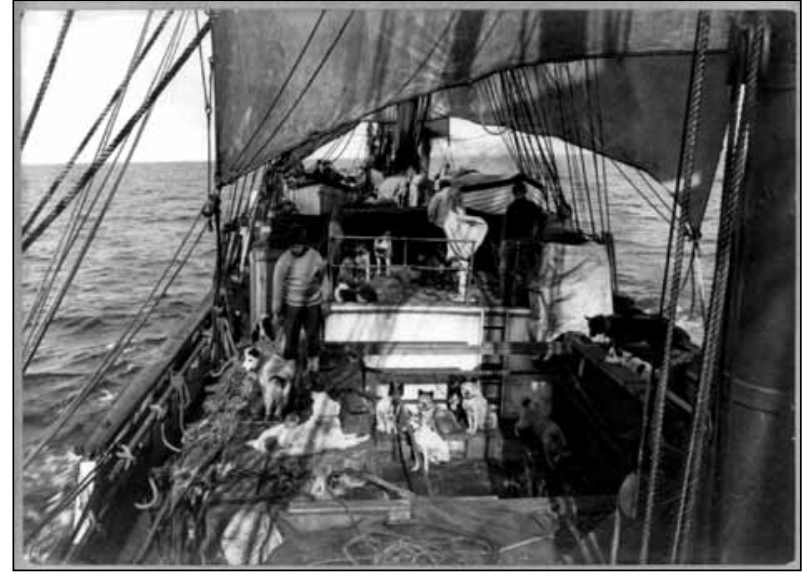

FIGURE 3 The dogs on the deck of the Terra Nova, 1910 (photographer: Herbert J Ponting). From the Library of Congress.

perhaps ill-advisedly, to feed his dogs chocolate; some of the dogs returned with him to Norway. ${ }^{20,21}$

As well as making vastly increased physical demands on his men by insisting on man-hauling of the sledges, Scott's men had a daily ration of $4,593 \mathrm{kcal}$, not very different from that of Amundsen's party, but this was reduced on the return journey due to dwindling supplies, in spite of the available depots laid on the inward journey. ${ }^{20}$ Until recently the daily calorific intake required for men man-hauling sledges was not known but, in 1993, Dr Mike Stroud and the explorer Sir Ranulph Fiennes set out, unsupported, to man-haul sledges across the Antarctic continent via the South Pole. It was a challenging experience and, according to Stroud's account, an unpleasant one. ${ }^{22}$ During the journey, glucose levels, weight and energy expenditure were monitored using recently developed techniques. The two men did not complete the journey due to exhaustion and were airlifted out but they did get well beyond the South Pole, so the expedition can be compared to that of Scott's journey to the South Pole and back. Man-hauling at $-30^{\circ} \mathrm{C}$ for $10-12$ hours a day across the polar surface was much more demanding than they had expected. Their daily rations gave them $5,500 \mathrm{kcal}$ and they also estimated the consumption of some body fat. In an attempt to increase this they binged on fatty food during their stay in South America before the last lap of their journey to Antarctica. ${ }^{23}$ They reported feeling continuously exhausted. The consumption of their own body fat started immediately and they both lost over 20 $\mathrm{kg}$ of body weight by the end of the journey. An ingenious procedure using doubly-isotopically labelled water $\left({ }^{2} \mathrm{H}_{1}\right.$ and $\left.{ }^{18} \mathrm{O}_{8}\right)$ enabled Stroud to determine, by examination of daily urine and blood samples, the levels of daily energy expenditure throughout the journey. At all times it was greater than intake from food and, during the ascent from the ice-shelf to the polar plateau (which lies at 10,000 feet), they each used around II,000 kcal 
per day, twice what the ration provided for. ${ }^{24}$ The nature of the ridged snow during the descent stage of Scott's return journey meant that his party would have expended a similar amount of energy.

With these figures as a guide we can estimate the physical condition of Scott's party, on reduced rations, during their return from the Pole. Malnutrition caused by man-hauling and the appalling weather they experienced were enough to kill even men with the stamina and grit of Scott and his companions. The layer of fat in the human body is an essential part of the body's defence against the effect of cold. The emperor penguin, whose eggs are incubated and hatched during the Antarctic winter, survives standing immobilised for days on end partly because of a $3 \mathrm{~cm}$ layer of body fat. ${ }^{25}$ If members of Scott's party lost substantial amounts of this fat, the effect of cold and the appalling weather would have been debilitating. Polar parties march on their stomachs, to paraphrase a remark attributed to Napoleon. Apsley Cherry-Garrard, a member of Scott's base camp party wrote a book ${ }^{26}$ describing the dreadful journey some of them made to the penguin rookery during the Antarctic winter in order to bring back pickled embryos of emperor penguins. He firmly believed that the deaths of those in Scott's South Pole party were due to the lack of food.

\section{VITAMIN C DEFICIENCY AND WOUNDS}

There is one member of the party, almost as famous as Scott himself, for whom scurvy may have proved an extra hardship during the return from the Pole: Captain Lawrence Oates. He was a soldier and joined Scott's party to care for the ponies. Scott may well have asked him to join the expedition so that the army would be represented. During the Second South African War Oates's thigh bone was badly damaged by a bullet and, although it had healed well, there was a large scar. It is stated in some accounts of Scott's expedition ${ }^{20,27}$ that scurvy can cause the opening of old wounds leading to intense pain and this may have been the immediate cause of Oates's exit from the tent during a blizzard, with the memorable words 'I am just going outside, I may be some time'. It is well established that vitamin $C$ is essential for the proper healing of fresh wounds and members of Scott's polar party suffered greatly because of this. ${ }^{28}$ Lack of vitamin $\mathrm{C}$ can also cause the dehiscence of partially healed wounds. However, the opening of old wounds due to this deficiency is another matter and well-documented cases are difficult to find. Bourne gives some anecdotal evidence from Lord Anson's round-theworld expedition in $1740-4 \mid$ and there are references in the writings of Lind $(1753)^{4}$ and Mead $(1762)^{29}$ but critical assessment of these historical examples is difficult. However there is a set of clinical observations that is particularly relevant to Oates's case. In 1939 John
Crandon, ${ }^{30,31}$ a young surgeon at Boston City Hospital subjected himself to a diet devoid of vitamin $C$ in order to assess its effect. After 4I days the vitamin was completely absent from his blood plasma but, even after 90 days, wound healing was still normal. However, fatigue rapidly became a major problem. At day 162 perifollicular haemorrhages developed on his lower legs and at day 180 a 15 year old appendicectomy wound began to disintegrate. This is approximately the same age as the scar from Oates's war wound and so it is possible that opening occurred as it appears that the age of the scar is no safeguard against disintegration. However, while this could have occurred there is no direct evidence that it did. The opening of the wound is not mentioned in Oates' diary or those of his companions. ${ }^{32}$ Wilson was a doctor and close to Oates and some would argue that it is unlikely that he would not have learned of it. However, Oates could have kept the condition of his wound to himself because he did not understand the significance or did not wish to cause alarm. Such a disability would have seriously impeded his progress, leading him to realise that it was impossible for him to keep up with his companions. This may have been a factor contributing to his decision to sacrifice himself. During his army career he was known as 'No Surrender' Oates and his decision to end his life must therefore have been the result of extreme provocation. It did however save him from a more lingering death from cold and malnutrition.

\section{CONCLUSION}

Did scurvy play any part in the death of Scott and his colleagues? There is evidence for and against scurvy as the cause of death ${ }^{33}$ and a definitive answer is unlikely. However, there are certain aspects of which we can be fairly certain. Because of the shortage of fresh food (and hence vitamin $C$ ) in the diet at both base camp and during the polar journey, it is likely that all members of the initial polar party suffered from some degree of scurvy. It is however a progressive condition and there is good evidence from all of the diaries that, with the exception of Lt Teddy Evans, no one had acute scurvy, the condition that heralds death. Some features such as bleeding gums, loose teeth and aching limbs are difficult to hide. Crandon did not get to this stage before he gave up his experiment. However, Teddy Evans did have bleeding gums and, instead of proceeding to the Pole, returned to base when the final selection of the polar party was made. Crandon's clinical studies give us some idea of the timescale for the onset of acute scurvy but he was on a diet of zero vitamin C while Scott's party had had some fresh meat at base camp and, even on the polar trip itself, had several meals of lightly cooked pony flesh following the sacrifice of one of the pack ponies. So one would expect members of Scott's party to survive without advanced scurvy for even longer than the time 
suggested by Crandon's work. Significantly, Teddy Evans had spent more time away from base camp sledging than the others and would have been without fresh food for a longer amount of time. At the same time, Crandon's work indicates how quickly scurvy gives rise to fatigue, and this would have seriously lengthened the journey time back from the Pole. Combine this with a serious underestimate of the energy expended in sledge-hauling and the exceptionally bad weather that Scott and his companions experienced (a topic discussed in detail by Solomon ${ }^{35}$ ), and it is clear why Scott's carefully calculated rations were inadequate and severe malnutrition resulted.Vigorous physical activity is a powerful antidote to the effect of cold so the fatigue caused by scurvy exacerbated the hypothermia that the intense cold caused. The death of Edgar Evans shortly after leaving the Pole has been plausibly credited to scurvy because of certain clinical symptoms, but also to a number of other medical conditions; the situation is complicated by the fact that he had a serious fall. So many diagnoses have been made that Guly ${ }^{33}$ concludes 'lack of more evidence makes further discussion somewhat fruitless'.

The cause of death of Scott and his remaining companions is most plausibly credited to the combination of frostbite, malnutrition and hypothermia, with the last two exacerbated by sub-acute scurvy. Had it been possible to prevent the onset of scurvy the party's hardship might have been reduced, but a successful return would still have been far from certain because of the other detrimental factors. In his book of photographs of polar travel, David Hempleman-Adams ${ }^{36}$ suggests that had Scott's party succeeded in getting to the Pole first they would have had the willpower to get back to base camp. This must be doubted; there is a limit to the power of the will over a sick body. Scurvy was just one of the unfortunate harmful influences affecting the party as it struggled on the return from the South Pole.

\section{Epilogue}

When news of Scott's achievement and tragic death on the return journey reached Great Britain, his reputation rose to unprecedented heights for an explorer. He was the sort of hero that appealed to the British public. Amundsen, on the other hand was perceived as a somewhat dubious character, who at the beginning of his voyage had indicated that he was going north and his change of plan was a shock to Scott. Yet he applied a professionalism to the task, in contrast to the gifted amateurism, grit and courage of Scott and his companions. Admiration for Scott was almost universal until 1979 when Roland Huntford published his influential book' on Scott and Amundsen, emphasising Scott's shortcomings as a leader, his lack of polar skills and the incompetence of his organisation of the expedition. In recent years, particularly in view of the centenary of Scott's death, Huntford's harsh judgment has been revised. Diana Preston's biography of $1997^{27}$ is far more sympathetic to Scott; Ranulph Fiennes' book ${ }^{32}$ is a robust, and largely convincing, defence of Scott as both a leader and as a man. Fiennes has the advantage of having experienced some of the situations in which Scott found himself.

Scott's hut has been restored in situ and remains a monument to his achievements. As significant has been the recognition of the scientific value of his expedition. Even during his return from the Pole the party took time to collect geological specimens and meticulous meteorological records were kept by both the polar party and those back at base. The discipline of climate science has benefitted from the records of Scott's party and some of the fossils collected gave the first indication that Antarctica was once warm enough to support the growth of trees. Scott's scientific achievements have been fully explored in a recent book by the American polar historian Edward Larson. ${ }^{37}$ For Amundsen the dash to the Pole was everything and all his skill and experience was dedicated to that end. Scott's aim was broader and, in spite of his shortcomings, he remains the more significant explorer. 


\section{REFERENCES}

I Huntford R. Scott and Amundsen. London: Hodder \& Stoughton; 1979.

2 Amundsen R. The South Pole: an account of the Norwegian Antarctic expedition in the Fram, 1910-1912 (trans. AG Chater). London: Digiread Publications; 2004.

3 Hopkins FG. Feeding experiments illustrating the importance of accessory food factors in normal dietaries.J Physiol 1912;44:425-60.

4 Lind J.Treatise of the scurvy. Edinburgh: Sands, Murray and Cochran; 1753.

5 Smith $\mathrm{AH}$. The relative content of antiscorbutic principle in limes and lemons, together with some new facts and old observations concerning the value of "lime juice" in the prevention of scurvy. The Lancet 1918; 192:737-8.

6 Dekker AO, Dickenson RG. Oxidation of ascorbic acid by oxygen with cupric ion as catalyst. J Am Chem Soc 1940; 62:2 I65-7I. http:// dx.doi.org//0.102I/ja01865a070

7 Hirschmann JV, Raugi GJ. Adult scurvy. J Am Acad Dermatol 1999; 4I:895-906. http://dx.doi.org/I0.1016/S0190-9622(99)70244-6

8 Huntford R. Shackleton. London: Hodder and Stoughton; 1985. PP. I 14-8.

9 Preston D. A first rate tragedy. London: Constable; 1997. p. 62.

10 Amundsen R. The South Pole: an account of the Norwegian Antarctic expedition in the Fram, 1910-1912 (trans. AG Chater). London: Digiread Publications; 2004. p. 723.

II Dunnill M. The Plato of Praed Street: the life and times of Almroth Wright. London: Royal Society of Medicine Press; 2000.

12 Wright AE. On the pathology and therapeutics of scurvy. The Lancet I900; I56:565-7. http://dx.doi.org/I0.I0I6/S0I406736(0I)99819-8

13 Lewis HE. Medical aspects of polar exploration:Sixtieth anniversary of Scott's last expedition. State of knowledge about scurvy in 1911. Proc R Soc Med 1972; 65:39-42.

14 Jones M. Robert Falcon Scott Journals. Oxford: Oxford University Press; 2005. pp. 269-70.

15 Holst A. Experimental studies relating to "ship beri-beri" and scurvy. JHyg I 907; 7:6 I 9-33.http://dx.doi.org/ I 0. I0I7/S0022 I 724000336 I I

16 Holst A, Frølich T. Experimental studies relating to ship-beri-beri and scurvy. J Hyg 1907; 7:634-7I. http://dx.doi.org/10.1017/ S0022I72400033623

17 Huntford R. Shackleton. London: Hodder and Stoughton; 1985. p. 236.

I8 Huntford R. Nansen: the explorer as hero. London: Gerald Duckworth \& Company; 1997.

19 Luca LM, Norum KR. Scurvy and cloudberries: a chapter in the history of nutritional sciences. J Nutr 20I I; I4I:210I-5. http:// dx.doi.org/I0.3945/jn. I I I.I45334

20 Vander der Merwe P, Preston D, Feeney R et al. South: the race to the pole. London: National Maritime Museum; 2000.
21 Huntford R. Scott and Amundsen. London: Hodder \& Stoughton; 1979. p. 58I.

22 Stroud M. Shadows on the wasteland. London: Jonathan Cape; 1993.

23 Stroud M. Survival of the fittest. London: Jonathan Cape; 1998. Chapter 5.

24 Stroud MA, Ritz P, Coward WA et al. Energy expenditure using isotope-labelled water $\left({ }^{2} \mathrm{H}_{1}^{18} \mathrm{O}_{8}\right)$, exercise performance, skeletal muscle enzyme activities and plasma biochemical parameters during 95 days of endurance exercise with inadequate energy intake. Eur J Appl Physiol Occup Physiol 1993; 76:243-52. http:// dx.doi.org/I0.1007/s0042I 0050243

25 Ancel A,Visser $\mathrm{H}$, Handrich $\mathrm{Y}$ et al. Energy saving in huddling penguins. Nature 1997; 385:304-5. http://dx.doi.org/I0.1038/385304a0

26 Cherry-Garrard A. Worst journey in the world:Antarctic 1910-1913. London: Constable and Company; 1922

27 Preston D. A first rate tragedy. London: Constable; 1997.

28 Peterkofsky B. Ascorbate requirement for hydroxylation and secretion of procollagen: relationship to inhibition of collagen synthesis in scurvy. Am J Clin Nutr 1991; 54:1135S-40S.

29 Bourne $\mathrm{GH}$. The effect of vitamin $\mathrm{C}$ on the healing of wounds. Proc Nutr Soc 1946; 4:204-16. http://dx.doi.org/I0.1079/PNSI946004I

30 Crandon JH, Lund CC. Vitamin C deficiency in an otherwise healthy adult. $N$ Eng J Med 1940; 222:748-52. http://dx.doi. org/I0.I056/NEJMI94005022221802

3I Lund CC, Crandon JH. Human experimental scurvy and the relation of vitamin $\mathrm{C}$ deficiency to postoperative pneumonia and to wound healing.JAMA 194I; I 16:663-8. http://dx.doi.org//0.100 I/ jama.194I.02820080003002

32 Fiennes R. Captain Scott. London: Hodder and Stoughton; 2003.

33 Guly $H$. The death of Robert Falcon Scott $(1869-1912)$ and colleagues. J Med Biogr 20I2; 20:160-3. http://dx.doi.org/I0.1258/ imb.20II.0II039

34 Jones M. Robert Falcon Scott Journals. Oxford: Oxford University Press; 2005. p. 422.

35 Solomon S. The coldest march: Scott's fatal antarctic expedition. New Haven and London; Yale University Press: 200I.

36 Hempleman-Adams D, Gordon S, Stuart E. The heart of the great alone: Scott, Shackleton and Antarctic photography. London: Royal Collection; 2009.

37 Larson EJ. An empire of ice: Scott, Shackleton and the heroic age of antarctic travel. New Haven:Yale University Press; 201 I. 